\title{
Зоряна Гбур
}

доктор наук з державного управління, доцент, професор кафедри управління охороною здоров'я та публічного адміністрування Національного університету охорони здоров'я імені П.Л.Шупика, м. Київ, Україна, е-таil: ernest-natan@ukr.net https://orcid.org/0000-0003-4536-2438

\section{Ернест Гбур}

студент 2-го курсу Інституту міжнародних відносин Київського національного університету імені Т.Г.Шечевнка, м. Київ, Україна, е-mail: ernest-natan@ukr.net

\section{ФІНАНСУВАННЯ МІЖНАРОДНОГО ТЕРОРИЗМУ - КЛЮЧОВІ МОМЕНТИ}

Анотація. Статтю присвячено висвітленню ключових моментів фінансування міжнародного тероризму. Автором зазначено, що сучасний рівень життя, непередбачувана геополітична ситуація, євроінтеграційні процеси, науково-технічний прогрес та багато інших обставин вимагають сьогодні від кожної держави економічного, соціального розвитку країни та суспільства, а також об'єднання зусиль для боротьби 3 найбільшим лихом наших днів - міжнародним тероризмом. У статті аналізуються історичні явища 3 позицій їх відповідності ознакам тероризму, показано розвиток методів і стратегій тероризму від античних часів до 20-го століття. Автором запропоновано сучасне розуміння поняття тероризму через призму правового явища.

Більше того, у статті розглянуто низку міжнародних нормативноправових актів, пов'язаних 3 організацією, вчиненням та викриттям тероризму. Розмежовано поняття «терор» та «тероризм». Наведено приклади системної протидії тероризму. Проаналізовано думки українських та зарубіжних науковців у сфері подолання тероризму.

У роботі встановлено, що останнім часом світ захлеснула хвиля терористичних актів і Україна, на жаль, теж входить в список країн, які страждають від цього явища. Як відомо, фінансування тероризму $є$ тим фундаментом, який дозволяє здійснювати вербування виконавців терористичних актів, забезпечувати їх грошима, зброєю, засобами зв'язку та пересування. Держави намагаються протидіяти фінансуванню тероризму. Однак вжиті заходи можуть входити в конфлікт з правами людини. А тому 
важливе значення набуває необхідність дотримання балансу інтересів особи i суспільства. В практиці Міжнародного Суду ООН щодо протидії фінансуванню тероризму важливим етапом став позов України проти Російської Федерації у зв’язку з порушенням двох міжнародних конвенцій.

Ключові слова: тероризм, терор, міжнародний тероризм, терористична організація, фінансування міжнародного тероризму, боротьбі 3 фінансуванням тероризму.

\title{
Zoriana Hbur
}

Doctor of Science in Public Administration, Associate Professor, Professor of the Department of Health Management and Public Administration of the PL Shupyk

National University of Health, Kyiv, Ukraine, e-mail: ernest-natan@ukr.net https://orcid.org/0000-0003-4536-2438

\section{Ernest Hbur}

\author{
2nd year student of the Institute of International \\ relations of Kyiv National University \\ named after Taras Shechevnko, Kyiv, Ukraine, \\ e-mail:ernest-natan@ukr.net
}

\section{FINANCING INTERNATIONAL TERRORISM - KEY POINTS}

\begin{abstract}
The article is devoted to highlighting the key points of financing international terrorism. The author notes that due to the current standard of living, unpredictable geopolitical situation, European integration processes, scientific and technological progress and many other circumstances, each state should develop in economic and social spheres, moreover, the states should combine efforts to combat the greatest disaster of our time - international terrorism. The article analyzes historical phenomena based on the signs of terrorism. The development of methods and strategies of terrorism from ancient times to the 20th century is also mentioned in the article. Taking into consideration the norms of international law, the author offers a modern view on the concept of terrorism.

Furthermore, the article considers a number of international legal instruments related to the organization and detection of terrorist acts. The concepts of "terror" and "terrorism" are distinguished. Examples of systemic actions to counterterrorism are given. The opinions of Ukrainian and foreign scientists on combating terrorism are analyzed in the article as well.

It's stated in the article that a wave of terrorist attacks has recently swept the world and, unfortunately, Ukraine is also on the list of countries suffering from this
\end{abstract}


phenomenon. It is well known that the financing of terrorism gives the perpetrators an opportunity to recruit new members, receive money, weapons, means of communication and transportation. States are trying to counter the financing of terrorism. However, the measures taken may violate human rights. Therefore, it is important to maintain a balance of interests of the individual and society. An essential part of the case law of the International Court of Justice on combating the financing of terrorism was Ukraine's lawsuit against the Russian Federation in connection with the violation of two international conventions.

Keywords: terrorism, terror, international terrorism, terrorist organization, financing of international terrorism, fight against terrorist financing.

Постановка проблеми. $\mathrm{Y}$ другій половині $\mathrm{XX}$ століття, ледве оговтавшись від наслідків, жаху та страждань, що були спричинені II Світовою Війною, міжнародне співтовариство нарешті зрозуміло, що питання дотримання міжнародного миру та правопорядку $\epsilon$ найбільш цінними, глобальними та потребують постійного контролю та удосконалення.

Однак, не дивлячись на створення Організації Об’єднаних Націй як універсальної організації, основним покликанням якої стало піклування про спокій та мир на міжнародній арені, міжнародне співтовариство стикнулося 3 новим дестабілізуючим світовий порядок фактором - тероризмом.

Нажаль, але на сучасному етапі існування людства все більше простежується ескалація терористичної діяльності, що проявляється в чіткій структурі міжнародних терористичних організацій, у наявності різноманітних «не класичних» видів терористичної діяльності, а саме: технологічної, економічної, комп’ютерної, релігійної, медіа-тероризму, тощо.

Дивлячись на статистику різноманітних терористичних актів, що трапились за останній 2020 рік, ми можемо говорити, що сьогодні активно прослідковується тенденція розширення масштабів терористичної діяльності, ускладнюється характер останньої, а форми, об'єкти та цілі терактів стають все більш жахливішими та показовими.

Враховуючи все вищезазначене, можемо сказати, що таке активне, різке та жорстке розповсюдження терористичної діяльності не можливе без існування значних потоків його фінансування. Адже, саме фінансування надає можливість для здійснення терористичних актів, забезпечуючи відповідну підготовку терористів, їх технічне оснащення та інші необхідні страти. Саме тому, ми вважаємо, що вирішення проблеми міжнародного тероризму слід розпочинати безпосередньо із боротьби 3 витоками його фінансування.

Отже, вважаємо, що міжнародному співтовариству в цілому і кожній державі зокрема необхідно розробити комплекс заходів організаційноправового, економічного та політичного характеру 3 метою виявлення та знищення будь-яких джерел фінансування чи будь-якої підтримки 
терористичних організацій, терористичних актів, тощо. Виходячи зі всього вищезазначеного, актуальність обраної теми для наукового дослідження не викликає сумніву, а є конче необхідною як для наукової доктрини, так і для практичної реалізації боротьби з фінансуванням міжнародного тероризму.

Аналіз останніх досліджень і публікацій. Питання фінансування міжнародного тероризму надзвичайно актуальне сьогодні i викликає підвищений науковий інтерес серед вчених правників, дослідників державноуправлінських процесів, міжнародників, політологів, тощо. Так, над вирішенням питань міжнародної терористичної діяльності сьогодні працюють такі вчені, як: В. Ф. Антипенко, Ю. М. Антонян, В. К. Грищук, В. П. Журавльов, В. М. Дрьомін, Н. А. Зелінська, В. П. Смельянов, В. В. Коваленко, В. А. Канарев, С. В. Лазебник, С. Я. Лихова та інші. Питанням наукового обгрунтування фінансування міжнародного тероризму присвячували свої наукові пошуки: Д.І. Аминов, Р. Вакульчук, Ю. Горбунов, В. Зубков, Т. Мельник, В. Петрищев, Д. Пчелкин, Е. Степанова, Я. Хаминский та інші.

Метою статті є теоретичне обгрунтування природи існування та функціонування міжнародного тероризму, шляхом дослідження сутності та формулювання дефініції поняття "міжнародний тероризм", розкриття змісту та функціональної основи поняття "фінансування міжнародного тероризму", а також детальний аналіз ключових моментів та реперних точок фінансування міжнародного тероризму.

Виклад основного матеріалу. Починаючи розгляд ключових моментів фінансування міжнародного тероризму вважаємо за необхідне звернутись до історії зародження та розвитку вказаного явища. Тож, опираючись на думки окремих науковців можна дійти висновку, що тероризм - це глобальна міжнародна проблема XX та XXI століття. Однак, звернувшись до історії розвитку та існування людської цивілізації, можемо простежити наявність терористичних організацій, які здійснювали свою діяльність ще у I-II столітті нашої ери. Як приклад, можна навести діяльність так званих сікаріїв на території Іудеї. Уолтер Локер у своїх дослідженнях вказує, що сікарії навмисно спалювали зерносховища та виводили 3 ладу системи водопостачання в Єрусалимі [1].

У XI столітті виникає секта ізмаліїтів - асасинів. Саме назва цих сектантів увійшла в європейські мови як визначення жорстоких та холоднокровних убивць. Це релігійне об'єднання виділялося незвичною для того часу стратегією боротьби із зовнішнім ворогом. За загальними підрахунками, на совісті секти асасинів більш сотні вбивств видних політичних та релігійних діячів. Ніщо не могло зберегти життя жертви вбивство було лише питанням часу. Хасан застосовував індивідуальний терор у всіх його формах. Він проявлявся у знищенні інакодумців або осіб, що становили небезпеку для держави, у провокаціях війни між державами та провокаціях війн між хрестоносцями [2].

Як бачимо, існування самого явища тероризму відомо історії ще 3 
найдавніших часів, не дивлячись на те, що народження безпосередньо самого терміну «терор», як проголошеної, мотивованої гаслами перетворення існуючого ладу легалізованої політичної сили, відбулося за часів Французької революції. Так, Едмунд Бюрк, перебуваючи в таборі супротивників влади революційних лідерів, дав визначенню насильницьким діям нового уряду Франції як “царювання терору”. Він був першим, хто публічно в 1795 році використовував слово «тероризм», застосувавши його в докладному описі самих актів терору [3, с. 42].

У 1848 році німецький радикал Карл Гейнцген стверджував, що заборону вбивства не можна застосовувати до політичної боротьби, а фізична ліквідація сотень і тисяч людей може бути виправдана, виходячи 3 «вищих інтересів людства». Гейнцген став певною мірою основоположником теорії сучасного тероризму. Він вважав, що силі й дисципліні реакційних військ необхідно було протиставити таку зброю, за допомогою якої невелика група людей може створити максимальний хаос. Тобто, в даному випадку Гейнцген сподівався дати асиметричну відповідь за допомогою отруйних газів, вибухівки, а також вимагав пошуку нових засобів знищення. Це і є так звана «філософія бомби», що з'явилася наприкінці XIX століття [4].

Як бачимо, тероризм i терористична діяльність фактично супроводжували людство на всіх віхах історії, а до практики тероризму неодноразово зверталися представники майже всіх народів світу. Тож, на нашу думку, недоречно стверджувати, що тероризм характерний лише для останнього історичного періоду розвитку людства, оскільки останній $є$ давно відомим видом протиправої діяльності.

Досліджуючи визначення поняття тероризму, заслуговує на увагу дефініція запропонована професором Р. Фалком, який зазначає: «Тероризм будь-який тип політичного насильства, що не має адекватного морального i юридичного виправдання, незалежно від того, хто до нього вдається революційна група або уряд». Зрозуміло, що вказане визначення $\epsilon$ досить умовним на відміну від визначення наданого Держдепартаментом США, за яким: «Тероризм - це заздалегідь обдумане, політично мотивоване насильство, що застосовується субнаціональними групами або підпільними державними агентами проти мішеней, які не беруть участі у військових діях» [6].

Як бачимо, у значній частині визначень тероризму міститься відсилання до іншого невизначеного поняття «терор», яке є латинським за походженням і у буквальному розумінні означає страх, жах. Словник сучасної української мови подає таке тлумачення поняття «терор»: 1) найгостріша форма боротьби проти політичних i класових супротивників iз застосуванням насильства аж до фізичного знищення; 2) надмірна жорстокість стосовно будь-кого; залякування [9].

Загалом підходи щодо співвідношення понять «терор» i «тероризм» можна поділити на дві групи. Перша - ототожнення цих понять, вживання їх, як синонімів. Друга - їх розмежування. Так, окремі автори, які вбачають відмінність між терором і тероризмом, розрізняють їх за різними критеріями, 
наприклад, що терор - це відкриті, демонстративні дії, а тероризм реалізується у конспіративних, нелегальних діях, інші вважають, що терор є насиллям i залякуванням, яке об'єктивно використовується сильнішим стосовно слабшого, а тероризм - це насилля i залякування, яке використовується слабшим стосовно сильнішого [10].

На нашу думку, найбільш обгрунтованим $є$ таке розмежування понять терору та тероризму: терор - це характеристика певного виду діяльності (надмірна жорстокість, що стосується будь-кого до кого-небудь, створення атмосфери страху тощо), натомість тероризм - це узагальнене позначення суспільно небезпечних діянь, які відповідною державою чи міжнародним співтовариством визнаються терористичними, злочинними (злочином чи сукупністю злочинів). Такий підхід, на нашу думку, обгрунтовується тим, що як ми вже зазначали, терористичні злочини не належать до юрисдикції жодного міжнародного суду чи трибуналу. Терористичні злочини (як вони визначені в універсальних документах про боротьбу 3 тероризмом) підпадають під дію національного кримінального законодавства 3 врахуванням відповідних міжнародних аспектів. Тобто, теоретично у національних законодавчих актах такі суспільно небезпечні діяння, з огляду на національні традиції та особливості побудови кримінального законодавства:

a) можуть бути названі по-різному (тероризм, терористичний акт тощо) i можуть вважатися кримінальним правопорушенням, злочином, деліктом;

б) можуть мати різну конструкцію (бути передбачені в одній статті або у кількох);

в) можуть мати як буквальне порівняно 3 міжнародними актами у цій сфері, так і розширене трактування;

г) національне законодавство може самостійно встановлювати ознаки таких злочинів, а може відсилати до міжнародних актів тощо.

Можна припустити, що 3 огляду на це, у міжнародному праві i використано узагальнене поняття тероризму, яке в узагальненому вигляді означає сукупність чи окремий терористичний злочин без деталізації їх (його) змісту за національним законодавством відповідної держави.

Як бачимо, міжнародний тероризм виходить за рамки загальноприйнятих державних кордонів та являє собою, в загальному, систему структурних зв'язків між терористичними організаціями та іншими суб'єктами терористичної діяльності. В соціально-політичній сфері міжнародний тероризм відображає конфліктну взаємодію різних сил, в основі якої, як правило, лежить боротьба за владу або володіння матеріальними та духовними цінностями [5].

Говорячи про сучасний тероризм, то можна стверджувати, що останній відрізняється висока організованістю та існуванням єдиного не лише керуючого центру, але і єдиним, уніфікованим центром фінансування. У той же час існують і мережеві структури, слабо або майже не пов'язані один 3 
одним і глибоко законспіровані групи, націлені на певні завдання. На сьогодні терористами використовуються всі останні наукові досягнення, докладаються зусилля щодо забезпечення і використання бактеріологічної, хімічної і ядерної зброї. Також, широко використовуються засоби масової інформації та Інтернет, як для залучення до себе уваги, так і для залякування людей та підтримки стану страху. Більше того, з розвитком прихованих сайтів, різноманітних прихованих платіжних систем та електронних валют фінансування терористичної діяльності відбувається активніше, однак носить занадто латентний характер.

Тож можемо стверджувати, що розвиток сучасних Інтернет-технологій суттєво вплинув на трансформацію загроз та викликів тероризму. Інтернет надає можливість встановлення прямих рівноправних зв'язків між виробником і споживачем, дозволяютчи обходитися без участі посередника $\mathrm{i}$ без конкуренції. Новітні технології постійно вдосконалюються, та нарощують потужність цифрових засобів здійснення терористичної діяльності. Виходячи з зазначеного вище, сьогодні дуже розповсюдженим є спонтанне формування абсолютно незалежних екстремістських груп, не пов'язаних 3 будь - яким центром. Подібні спонтанні групи виявити практично неможливо. Тактику і способи проведення терактів такі люди черпають з Інтернету та засобів масової інформації [7].

Не підлягає сумніву теза про те, що міжнародний тероризм представляє загрозу як для міжнародного правопорядку і міждержавних відносин, так i для для міжнародної безпеки і міжнародних інтересів держав. Залежно від характеру скоєних терористичних акцій, даний вид тероризму може досить серйозно зачіпати i внутрішньополітичні інтереси окремих країн та політичних організацій. У зв'язку 3 цим попередження або припинення терористичних актів та, звичайно таки, фінансування тероризму обумовлює необхідність співпраці держав у захисті їхніх спільних інтересів [5].

Враховуючи вказані фактори, ще в 1994 році була прийнята Декларація про заходи щодо ліквідації міжнародного тероризму. В ній зазначено, що держави зобов'язані виконувати зобов'язання щодо боротьби 3 міжнародним тероризмом, і їм настійно пропонується вжити ефективних і рішучих заходів згідно 3 відповідними положеннями міжнародного права i міжнародних стандартів прав людини для якнайшвидшої i остаточної ліквідації міжнародного тероризму. Заходи включають утримання від організації терористичної діяльності, забезпечення затримання та судового переслідування осіб, які вчинили терористичні акти, прагнення до укладання угод з метою запобігання міжнародному тероризму та інше [6].

Не дивлячись на досить тривалу історію розвитку самого явища тероризму i практику боротьби людства 3 діяльністю терористичних організацій, питанням щодо запобігання фінансування тероризму міжнародне співтовариство почало займатись лише в другій половині XX століття. Безпосередньо питанням протидії фінансуванню тероризму присвячена Міжнародна конвенція про боротьбу 3 фінансуванням тероризму, яку 
прийнято резолюцією 54/109 Генеральної Асамблеї ООН від 9 грудня 1999 p. [11].

Положення вказаної Конвенції наполегливо рекомендують усім державам-учасницям установити у власному національному законодавстві кримінальну відповідальність за фінансування тероризму. Зокрема, у статті 4 Конвенції йдеться: «Кожна держава-учасниця вживає таких заходів, які можуть бути необхідними: а) для визнання кримінальними злочинами згідно 3 iіi внутрішнім законодавством злочинів, зазначених у статті 2; b) для встановлення за ці злочини відповідних покарань 3 урахуванням тяжкості цих злочинів» [11].

У статті 2 Конвенції вказуються ознаки фінансування тероризму як злочину, які повинні бути враховані при встановленні кримінальної відповідальності за це діяння в національних законодавствах. Конвенція вимагає, щоб учасники робили кроки, з тим щоб перешкоджати і протидіяти фінансуванню терористів, незалежно від того, чи здійснюється таке фінансування прямо або опосередковано через організації, які стверджують, що переслідують благодійні, громадські або культурні цілі, або також залучені в заборонені види діяльності, такі, як незаконний обіг наркотиків, поставки зброї, контрабанда нафтопродуктів; зобов’язує держави залучати тих, хто фінансує тероризм, до кримінальної, цивільної чи адміністративної відповідальності за такі діяння; передбачає виявлення, блокування та арешт фондів, призначених для терористичної діяльності, а також розділ з іншими державами конфіскованих коштів в кожному випадку окремо. Банківська таємниця більш не є достатньою підставою для відмови у співпраці.

Виходячи з вищезазначеного під фінансуванням тероризму вважаємо за необхідне розуміти - надання чи збір активів будь-якого роду 3 усвідомленням того, що їх буде використано повністю або частково для будьяких цілей окремим терористом, терористичною групою або терористичною організацією, для організації, підготовки і вчинення окремим терористом, терористичною групою або терористичною організацією визначеного Кримінальним кодексом України терористичного акту, втягнення у вчинення терористичного акту, публічних закликів до вчинення терористичного акту, створення терористичної групи чи терористичної організації, сприяння вчиненню терористичного акту, будь-якої іншої терористичної діяльності, а також спроби здійснення таких дій.

Зазвичай, фінансування тероризму включає не лише фінансування терористичних актів як таких, але й підтримку злочинної інфраструктури. Таким чином, фінансування тероризму передбачає не тільки підготовку i здійснення терористичних актів, а й їх організаційне забезпечення, пропаганду ідеології, вербування, навчання та підготовку нових членів організації, виплати хабарів, пересування між містами чи країнами. Крім того, частина коштів може бути використана для створення видимості законної діяльності, зокрема підконтрольних структур, що займаються комерційною чи кредитно-фінансовою діяльністю [13, с. 80]. 
Для прикриття фінансування тероризму злочинці можуть застосовувати низку методів, що передбачають використання фінансової інфраструктури. До фінансування терористичної діяльності можуть бути залучені банки, небанківські установи, благодійні організації, неприбуткові організації, альтернативні системи переказу грошей (хавала та ін.). Рух коштів може здійснюватися як через міжнародні системи переказу коштів, так і через невеликі регіональні платіжні системи. Розвиток новітніх платіжних технологій, легкість та швидкість здійснення фінансових транзакцій у глобальному масштабі у поєднанні з великою кількістю неофіційних (чи напівофіційних) систем переказу грошей створюють передумови для зростання ризиків використання фінансової системи для цілей фінансування тероризму.

Аналіз даних щодо розслідувань операцій, пов'язаних із фінансуванням тероризму, свідчить, що часто для подібних операцій використовувалися такі платіжні системи як MoneyGram, WesternUnion, Золота корона, Yandex гроші та Гроші@mail.ru. Використання готівки, а також іiі внесення на рахунки під виглядом фінансової допомоги, позик чи грантів також $є$ поширеним явищем [14].

Слід зазначити, що способи фінансування терористичних організацій еволюціонують паралельно з розвитком можливостей фінансового сектора у сфері руху грошей, тому поряд 3 переліченими відомими інструментами цілком можуть використовуватися i такі, що передбачають складні транскордонні багатоходові схеми, виявлення яких може стати складним завданням для фінансових установ. Використання фінансової системи злочинцями, які займаються фінансуванням тероризму, $\epsilon$ загрозою стабільності фінансової системи. Найчастіше фінансові установи, насамперед банки, виступають головними посередниками фінансових транзакцій. За даними Державної служби фінансового моніторингу України, банки є найбільш активними учасниками первинного фінансового моніторингу, що реєструють переважну більшість повідомлень про операції, які підлягають фінансовому моніторингу [13].

Закономірно, що у випадку, коли така значна частка фінансових потоків у країні рухається через банки, то і ризик здійснення операцій з фінансування терористичної діяльності 3 використанням банківського сектора слід розглядати як доволі високий. Важливе значення для ефективної протидії фінансуванню тероризму має синергія зусиль i взаємодія банків та небанківських фінансових установ, Державної служби фінансового моніторингу, а також правоохоронних органів. Забезпечення оперативного обміну інформацією між державним та приватним сектором, між фінансовим сектором та правоохоронними органами має стати невід'ємним елементом при побудові стратегії протидії фінансуванню тероризму [14].

Особливий акцент слід зробити на процедурі розслідування справ, пов'язаних із фінансуванням терористичної діяльності, та ефективності роботи правоохоронних органів. Адже інформування банками про підозрілі 
фінансові операції та зупинення таких операцій є недостатнім у разі, коли у подальшому їх ініціатори чи бенефіціари не притягаються до кримінальної відповідальності.

В практиці Міжнародного Суду ООН щодо протидії фінансуванню тероризму важливим етапом став позов України проти Росії, який вона подала 16 січня 2017 року у зв’язку 3 порушенням Кремлем двох міжнародних конвенцій - про боротьбу з фінансуванням тероризму та про ліквідацію всіх форм расової дискримінації. Аргументи заяви України зводяться до того факту, що Російська Федерація надає зброю та інші види допомоги незаконним збройним формуванням, які вчинили низку терористичних актів на території України. Крім того, українські представники наполягають на визнанні участі Росії в кампанії дискримінації щодо неросійських громад, які проживають на окупованій території Кримського півострова, зокрема, спільнот етнічних українців та кримських татар. 3 огляду на вищезазначене, Україна вкотре вимагає притягнення Російської Федерації до відповідальності за порушення міжнародного права і просить Міжнародний суд ООН на час розгляду справи, в якості заходу забезпечення позову, заборонити РФ здійснювати будь-які кроки, що погіршують нинішню ситуацію.

Також українська сторона вимагає від Росії припинення підтримки збройних формувань на українській території; відшкодування репарації всім, хто постраждав через дії проросійських збройних формувань; повного відновлення в правах української та кримськотатарської громад на окупованій території України, а саме в Криму та Севастополі. Наскільки вдалим для України буде рішення суду - покаже час, проте сам факт позову свідчить про позитивну тенденцію впевненого відстоювання Києвом власної позиції на міжнародній арені. Складність в тому, що практика розгляду справ щодо порушень норм Конвенції про боротьбу з фінансуванням тероризмом в Міжнародному суді відсутня, але ця міжнародна угода - єдина, за якою Суд може встановити наявність юрисдикції [10].

На жаль, як бачимо, явище міжнародного тероризму розвивається значно скоріше, ніж світове співтовариство через наявні в нього механізми норми міжнародного права встигає ефективно реагувати на нього i, як наслідок, існують значні прогалини в міжнародно-правовому регулюванні протидії фінансуванню міжнародного тероризму. А отже, даний напрям потребує вдосконалення.

Виходячи зі всього вищезазначеного, вважаємо за необхідне запропонувати наступні напрямки підвищення ефективності міжнародноправового регулювання боротьби з фінансуванням тероризму:

1) Введення міжнародно-правової відповідальності держав, що прямо чи опосередковано сприяють фінансуванню міжнародного тероризму та підтримують терористичні рухи.

2) Взаємне визнання переліків фізичних та юридичних осіб, що визнані 
на національних рівнях причетними до фінансування терористичної діяльності та замороження їх активів на територіях всіх держав.

3) Спрощення процедури імплементації в національне законодавство міжнародно-правових норм в боротьбі 3 фінансуванням тероризму та забезпечення на національному рівні обов’язкової реакції на резолюції РБ $\mathrm{OOH}$.

4) Тісніша взаємодія з приватним сектором.

5) Проведення державами взаємних оцінок, консультацій та взаємне надання технічного сприяння в боротьбі з фінансуванням тероризму.

Висновки. Отже, 3 проведеного нами дослідження вбачається, що тероризм на сьогодні $\epsilon$ реальною та небезпечною загрозою для світового співтовариства. Міжнародний тероризм не знає кордонів та має здатність впливати як на внутрішні інтереси країн, так і на міждержавні відносини. У зв’язку з розвитком новітніх технологій відбулась трансформація сучасного тероризму, $є$ тенденція до збільшення терористичних актів та кількості жертв. Боротьба з тероризмом $є$ не тільки складним i заплутаним, але i довгостроковим завданням. Тому сьогодні особливо актуальною стає проблема створення світових, регіональних i національних систем колективної безпеки. Виникла політична необхідність і економічна доцільність формування життєздатної, міжнародної, колективної системи, яка буде здатна протистояти будь-якій внутрішній і зовнішній військової експансії та тероризму.

У статті приходимо до висновку, що сучасний тероризм не може функціонувати без фінансової підтримки. Така підтримка може надходити 3зовні, проте ймовірність руху коштів через фінансові установи всередині країни також слід оцінювати як високу. Фінансовий сектор в Україні $\epsilon$ банкоцентричним, тому саме банки найчастіше зіштовхуються з незаконними фінансовими операціями i саме вони надсилають більшу частину повідомлень про підозрілі операції, які підлягають фінансовому моніторингу. Така ситуація зумовлена i тим, що у банківських установ ефективніші механізми ідентифікації та верифікації клієнтів та більш налагоджена співпраця 3 спеціально уповноваженими органами. Процедури небанківського сектору щодо протидії відмиванню грошей та фінансуванню тероризму за своєю ефективністю поступаються банківським і потребують вдосконалення. Наріжним каменем для формування інструментарію протидії фінансуванню тероризму є законодавчо-нормативна база, стан якої в Україні можна вважати задовільним і таким, що значною мірою відповідає вимогам міжнародних стандартів.

У контексті дотримання вимог законодавства фінансові установи повинні зорієнтувати свою діяльність на застосування ризикоорієнтованого підходу в процесі ідентифікації та верифікації клієнтів, моніторингу їх транзакцій, своєчасне виявлення та блокування фінансових операцій, щодо яких є підозра, що вони можуть бути пов'язані із фінансуванням тероризму. 
Важливе значення для встановлення бар'єрів на шляху руху коштів до терористичних організацій відіграє оперативний обмін інформацією між фінансовим сектором та правоохоронними органами, а також співпраця 3 відповідальними за боротьбу з тероризмом органами інших країн. Питання протидії фінансуванню тероризму та розповсюдженню зброї масового знищення для України буде актуальним ще тривалий час. Поглиблених досліджень потребуватимуть схеми фінансування терористичних організацій, фінансові інструменти, які вони використовують, механізми протидії залученню такими організаціями коштів із за кордону. Поряд 3 тим, слід звернути увагу також на особливості використання для залучення коштів терористичними організаціями інноваційних фінансових інструментів, зокрема криптовалют, щодо яких наразі відсутнє належне регулювання та нагляд.

Більше того, у результаті дослідження нами встановлено, що заходи, вжиті з метою протидії фінансуванню тероризму можуть входити в конфлікт 3 правами людини. А тому важливе значення набуває необхідність дотримання балансу інтересів особи і суспільства, що і буде предметом наших подальших наукових пошуків.

\section{Jimepamypa:}

1. У. Лакер. Истоки. Иностранная литература 1996, № 11. Перевод с английского С. Белова.

2. Борисова О.В., Кузьмін С.А., Карпенко Д.М. До питання про історичні аспекти виникнення тероризму. URL: file:///C:/Users/Acer/Downloads/boz_2009_20_20.pdf

3. Richard Haas "The Next Word Order", The New Yorker, 1 April 2002. P. 42.

4. Печенюк I., Шевченко М. Витоки та сутність міжнародного тероризму "Воєнна історія" \#4_6 за 2004 рік. URL: http://warhistory.ukrlife.org/4_6_04_6.htm

5. Гринчук М. Сучасні виклики та загрози міжнародного тероризму. URL: file:///C:/Users/Acer/Downloads/3126-11486-1-PB.pdf

6. Понятие терроризма и его современные разновидности. Понятие «терроризма» и методологические проблемы его изучения. URL: http://www.politictime.ru/potis-339-1.html.

7. National Consortium for the Study of Terrorism and Responses to Terrorism: Annex of Statistical Information. URL: https://www.state.gov/j/ct/rls/crt/2015/257526.htm.

8. Декларация о мерах по ликвидации международного терроризма URL: http://www.un.org/ru/documents/decl_conv/declarations/terrdec1.shtml.

9. Великий тлумачний словник сучасної української мови / укл. і гол. ред. В. Т. Бусел. К.; Ірпінь: Перун, 2005. 1728 с.

10. Канцір В. Серкевич I. Сучасне розуміння поняття тероризму. 2017. URL: http://science.lpnu.ua/sites/default/files/journal-paper/2018/jun/13445/70.pdf

11. Международная конвенция о борьбе с финансированием терроризма. (Резолюция 54/109 Генеральной Ассамблеи ООН от 9 декабря 1999 г.) URL: http://www.un.org/ru/documents/decl_conv/conventions/terfin.shtml

12. Баранов О.П. Фінансування міжнародного тероризму як загроза національній безпеці. Державне управління. 2018. Вип.9. С. 108-112.

13. Рисін В.В., Степанова А.В. Інструменти протидії фінансуванню тероризму 3 використанням фінансових установ. Економіка та держава. 2020. Вип. 6. С. 80-86.

14. Combating the Financing of Terrorism (CFT) (2020), Investopedia. URL: https://www.investo\$ pedia.com/terms/c/combating\$financing\$terrorism\$cft.asp 
15. Огляд міжнародної безпеки. Аналітика 3 України. Проект ГО «Центр міжнародної безпеки» URL: http://conflicts.

16. Кононенко В.П., Новікова Л.В. Фінансування тероризму - загроза для міжнародних відносин. Практика міжнародного суду ООН та Суду ЄС. Вісник Харківського Національного університету мені В.Н. Каразіна. 2018. Вип. 7. С. 55-59.

\section{References:}

1. Laqueur, W. Z. (1996). Istoki [Origins]. Inostrannaya literatura - Foreign Literature, 11. Retrieved from https://magazines.gorky.media/inostran/1996/11/istoki.html [in Russian].

2. Borysova, O.V., Kuzmin, S.A., Karpenko, D.M. (2009). Do pytannia pro istorychni aspekty vynyknennia teroryzmu [On the question of historical aspects of terrorism]. Borotba $z$ orhanizovanoiu zlochynnistiu $i$ koruptsiieiu (teoriia i praktyka) - Fight against organized crime and corruption (theory and practice), 20, 177-182. Retrieved from http://nbuv.gov.ua/UJRN/boz_2009_20_20 [in Ukrainian].

3. Haas, R. (2002). The Next Word Order. The New Yorker. 1 April [in English].

4. Pecheniuk, I., Shevchenko, M. (2004). Vytoky ta sutnist mizhnarodnoho teroryzmu [Origins and essence of international terrorism]. Voienna istoriia - Military History, 4(6). Retrieved from http://warhistory.ukrlife.org/4_6_04_6.htm [in Ukrainian].

5. Hrynchuk, M. (2017). Suchasni vyklyky ta zahrozy mizhnarodnoho teroryzmu [Modern methods and technologies of information terrorism]. Mediaforum, 5, 64-75. Retrieved from http://en.chnu.edu.ua/wp-content/uploads/2018/03/64-Гринчук.pdf [in Ukrainian].

6. Ponyatie terrorizma i ego sovremennye raznovidnosti. Ponyatie «terrorizma» i metodologicheskie problemy ego izucheniya [The concept of terrorism and its modern varieties. The concept of "terrorism" and methodological problems of its study]. www.politictime.ru. Retrieved from http://www.politictime.ru/potis-339-1.html [in Russian].

7. National Consortium for the Study of Terrorism and Responses to Terrorism: Annex of Statistical Information. www.state.gov. Retrieved from https://www.state.gov/j/ct/rls/crt/2015/257526.htm [in English].

8. Deklaratsiya o merakh po likvidatsii mezhdunarodnogo terrorizma [Declaration on Measures to Eliminate International Terrorism]. www.un.org. Retrieved from http://www.un.org/ru/documents/decl_conv/declarations/terrdec1.shtml [in Russian].

9. Busel, V. T. (Eds.). (2005). Velykyi tlumachnyi slovnyk suchasnoi ukrainskoi movy [Large explanatory dictionary of the modern Ukrainian language]. Kyiv; Irpin: Perun [in Ukrainian].

10. Kantsir, V., Serkevych, I. (2017). Suchasne rozuminnia poniattia teroryzmu [Modern understanding of the concept of terrorism]. Visnyk Natsionalnoho universytetu "Lvivska politekhnika". Seriia: Yurydychni nauky - Bulletin of the National University "Lviv Polytechnic". Series: Legal Sciences, 865, 449-456. Retrieved from http://science.lpnu.ua/sites/default/files/journal-paper/2018/jun/13445/70.pdf [in Ukrainian].

11. Mezhdunarodnaya konventsiya o borbe s finansirovaniem terrorizma. (Rezolyutsiya 54/109 General'noy Assamblei OON ot 9 dekabrya 1999 g.) [International Convention for the Suppression of the Financing of Terrorism. (Resolution 54/109 of the UN General Assembly of December 9, 1999)]. www.un.org. Retrieved from http://www.un.org/ru/documents/decl_conv/conventions/terfin.shtml [in Russian].

12. Baranov, O.P. (2018). Finansuvannia mizhnarodnoho teroryzmu yak zahroza natsionalnii bezpetsi [Financing of international terrorism as a threat to national security]. Derzhavne upravlinnia - Governance, 9, 108-112 [in Ukrainian].

13. Rysin, V.V., Stepanova, A.V. (2020). Instrumenty protydii finansuvanniu teroryzmu z vykorystanniam finansovykh ustanov [Counter-terrorist financing tools using financial institutions]. Ekonomika ta derzhava - Economy and state, 6, 80-86 [in Ukrainian]. 
14. Combating the Financing of Terrorism (CFT) (2020). www.investopedia.com. Retrieved from https://www.investopedia.com/terms/c/combating-financing-terrorism-cft.asp [in English].

15. Ohliad mizhnarodnoi bezpeky. Analityka z Ukrainy. Proekt HO «Tsentr mizhnarodnoi bezpeky» [Review of international security. Analytics from Ukraine. Project of the CO "Center for International Security"]. conflicts.in.ua. Retrieved from http://conflicts.in.ua [in Ukrainian].

16. Kononenko, V.P., Novikova, L.V. (2018). Finansuvannia teroryzmu - zahroza dlia mizhnarodnykh vidnosyn. Praktyka mizhnarodnoho sudu OON ta Sudu YeS [Terrorism financing is a threat to international relations. The case law of the International Court of Justice and the Court of Justice]. Visnyk Kharkivskoho natsionalnoho universytetu imeni $V$. N. Karazina. Seriia: Mizhnarodni vidnosyny. Ekonomika. Krainoznavstvo. Turyzm - The Journal of V. N. Karazin Kharkiv National University. Series: International Relations. Economics. Country Studies. Tourism, 7, 55-59 [in Ukrainian]. 